\title{
Regulation of Integrin $\beta 3$ Protein Secretion on Implantation Embryo of Mouse (Mus musculus L.) Induced by Oil Atsiri of Purple Nutsedge Tubers (Cyperus rotundus L.)
}

\author{
Hendri Busman $^{1^{*}}$, Sutyarso $^{1}$, Salman Farisi ${ }^{1}$ and Yulianty ${ }^{1}$ \\ ${ }^{1}$ Department of Biology, Faculty of Mathematics and Natural Sciences, University of Lampung, \\ Indonesia.
}

Authors' contributions

This work was carried out in collaboration among all authors. Author HB designed the study, performed the statistical analysis, wrote the protocol, and wrote the first draft of the manuscript. Author Sutyarso managed the analyses of the study. Authors SF and Yulianti managed the literature searches. All authors read and approved the final manuscript.

Article Information

DOI: 10.9734/ARRB/2019/v33i230119

Editor(s):

(1) Dr. Gonzalo Emiliano Aranda Abreu, Brain Research Center, Veracruzana University, Veracruz, Mexico.

Reviewers:

(1) Juliano Augusto, Brum Scheffer, Brazil. (2) Abdelaziz Soukri, University Hassan li of Casablanca, Morocco.

(3) Omotunde Okubanjo, University of Lagos, Nigeria. Complete Peer review History: https://sdiarticle4.com/review-history/51966

Original Research Article

Received 02 August 2019

Accepted 12 October 2019

Published 22 October 2019

\begin{abstract}
Aims: This study aims to determine the regulation of $\beta 3$ integrin protein in the period of embryo implantation after being induced by oil atsiri of purple nutsedge tubers.

Study Design: The study employed a completely randomised design using four concentration levels repeated six times.

Place and Duration of Study: Organic Chemistry Laboratory and Zoology Laboratory of Faculty of Mathematics and Natural Sciences University of Lampung, between June 2015 and April 2016.

Methodology: This study used mouse as experimental animals with 24 female mouse, then mated with male mouse with a ratio ( 1 female: 1 male). After the vaginal plug was found in female mouse, then the essential oil of purple nutsedge tubers was induced orally (force-fed) according to the treatment dose. Each 6 female mice were grouped as a control group, and 3 treatment groups, consisting of controls $(C)=0.4 \mathrm{ml}$ aquabides, treatment $1(\mathrm{~T} 1)=4.5 \mathrm{mg} / 40 \mathrm{~g}$ body weight,
\end{abstract}


treatment $2(\mathrm{~T} 2)=45 \mathrm{mg} / 40 \mathrm{~g}$ body weight, and treatment $3(\mathrm{~T} 3)=135 \mathrm{mg} / 40 \mathrm{~g}$ body weight. After the one way Anova test, Ho is rejected, meaning there are significant differences and the analysis is continued with multiple comparison tests, in this case the Least Significant Difference (LSD) test is used.

Results: The results shown that the induction of essential oils of purple nutsedge tubers can reduce the level of $\beta 3$ integrin protein in uterus mouse significantly.

Conclusion: It is suggested essential oil of purple nutsedge tubers has potential decrease and can reduce the level of $\beta 3$ integrin protein in uterus mouse during the period of embryo implantation.

Keywords: Cyperus rotundus L.; purple nutsedge tubers; essential oils; implantation embryo; $\beta 3$ integrin.

\section{INTRODUCTION}

This study aims to determine the role of the $\beta 3$ integrin protein as a receptor for matrix proteins, and an important role in the interaction between tropectoderm and uterine epithelium. Some components that play a role in the process of embryo implantation include cytokines, adhesion molecules [1,2] and proteolytic enzymes [3]. Integrin and fibronectin, trophinin, tastin and blystin are adhesion molecules expressed both in blastosis and endometrium of the uterus and are believed to play a role in the process of implantation [2,4].

These molecules are functional proteins that activate signals in cells during embryo implantation. Functional proteins that regulate certain biological processes are known as regulatory proteins $[5,6]$. Regulatory proteins secreted during implantation can be classified as signaling proteins $[7,8]$. Signaling protein in the process of implantation is a protein that plays a role in the process of cell adhesion through activation of signals in cells [7]. The protein is secreted in small amounts, with varying amounts depending on differences in size and relative solubility in water [8].

The integrin protein has a role in influencing and mediating adhesion, migration, invasion and cellular signaling. The $\alpha v \beta 3$ and $\alpha 4 \beta 1$ integrin proteins are markers of the uterus. Av $\beta 3$ integrin shows high expression in embryo attachment, so avß3 integrin is associated with infertility problems [9]. In the endometrium, cytotropoblasts participate in regulating the expression of integrins. The expression of $\beta 3$ integrins in the glandular and luminal epithelium will increase regulation because it coincides with the implantation window of endometrial receptivity. In addition, tropectoderm blastosis also expresses several integrins such as $\alpha 3, \alpha 5$, $\beta 1, \beta 3, \beta 4$ and $\beta 5$, thought to involve binding of blastocysts on the endothelial surface [10].

On the other hand, some plants including the puzzle grass tubers are as antifertility, especially as blastocytotoxic [11]. In the research results of chloroform extract and methanol tubers of puzzles of grass, are known to have a cytotoxic effect on HeLa cells and SiHa cells (cervical cancer cells) [12]. Kilani et al. [13] have conducted research by testing the tubers of puzzles on leukemia cells (L1210). The results showed a cytotoxic effect by inducing apoptosis. In this connection, the extract of the puzzle grass tuber indicates endometrial dysfunction. This condition can be used as a clinical marker in the assessment of endometrial receptivity for infertile women.

\section{MATERIALS AND METHODS}

\subsection{Production of Purple Nutsedge Tubers Essential Oil}

The initial process in this research is to identify and determine the plants that will be used based on observing the morphological characteristics of plants such as flowers, leaves, stems, roots and tubers. The tubers are washed clean, then dried at room temperature for about one week, after that chopped into small size. A total of $10 \mathrm{~kg}$ of simplicia purple nutsedge tubers distilled Stahl with distilled water $2 / 3$ the contents of the flask and heated at a temperature of $100^{\circ} \mathrm{C}$ for 3 hours until a mixture of oil and water is obtained (until no essential oil drops are formed). Then the oil mixture is evaporated in vacuo at low temperatures to obtain essential oils of tubers. After that the essential oil is separated, the essential oil which is still mixed with a little water is removed by adding $\mathrm{MgSO}_{4} \quad 7 \mathrm{H}_{2} \mathrm{O}$ until saturated and then separated. The essential oil obtained is used as a sample for the next process. 


\subsection{Determination of Doses of Purple Nutsedge Tubers Essential Oil}

According to Sa'roni and Wahjoedi (2002) [14] about "the effect of infusion of rhizome of turf grass on the estrous cycle and uterine weight in white rats", the treatments given are:

Control group with $1 \mathrm{ml} / 100 \mathrm{~g}$ body weight (A)

Dosage group $11.25 \mathrm{mg} / 100 \mathrm{~g}$ body weight (B)

Dosing group $112.5 \mathrm{mg} / 100 \mathrm{~g}$ body weight (C)

Dosing group $337.5 \mathrm{mg} / 100 \mathrm{~g}$ body weight (D)

The dosage was obtained from the $11.25 \mathrm{mg}$ purple sedge tubers extract and was given to the white rat weight tested animal; $100 \mathrm{~g}(2.5 \mathrm{x}$ body weight of mice), then converted to body weight of mice randomly grouped into 4 groups, so that the dose of the essential oil of tubers used in this study are:

1. Group $\mathrm{C}$ was given $0.4 \mathrm{ml}$ of aquabides as a control

2. Group T1 (treatment 1 ) is given a dose of $4.5 \mathrm{mg} / 40 \mathrm{~g}$ body weight in $0.4 \mathrm{ml}$ of aquabides

3. Group T2 (treatment 2) is given a dose of $45 \mathrm{mg} / 40 \mathrm{~g}$ body weight in $0.4 \mathrm{ml}$ of aquabides

4. Group T3 (treatment 3) was given a dose of $135 \mathrm{mg} / 40 \mathrm{gr}$ body weight in $0.4 \mathrm{ml}$ of aquabides

\subsection{Provision of Purple Nutsedge Tubers Essential Oil in Experimental Animals}

Mice maintained in laboratory conditions that are controlled by feeding and drinking are given $a d$ libitum. The study was conducted in a series of stages. The first step is mating by combining one female mouse with one male mouse. Mated female mice are characterized by the formation of a vaginal plug. The day the vaginal plug was found was assumed to be the first day of pregnancy. In this study the control animal estrous cycle was determined by vaginal smears. The second stage is the maintenance of mice that have been mated. Mice that have been mated or that have been determined to have estrous phases are separated and maintained in a solitary cage. Then each treatment group was given a fraction of the essential oil of the tuber according to the dose of the treatment by means of being fed (orally) using a syringe whose edges were blended and given a small rubber pipe. The scraping is done once a day for 6 days, to determine the effect of the purple sedge tubers essential oil fraction on experimental animals.

\subsection{Statistical Analysis}

Data were analyzed using the data normality test (Kosmogorov-Smirnov test), while the homogeneity of the data tested using the Levene test. Criteria for testing decisions is if the Sig/pvalue is highter than alpha $=0.05$ then it is said that the data is normally distributed. While the test decision criteria in the Levene test are homogeneous sample data if the Sig or $p$-value> $\alpha=0.05$. The data then proceed by oneway Anova test. If the one way Anova test results in the conclusion $\mathrm{Ho}$ is rejected, it means that there are significant differences and the analysis is continued with a multiple comparison test, in this case the Least Significant Difference (LSD).

\section{RESULTS AND DISCUSSION}

The homogenity test of variance based on the Levene test shows that the value is (0.501> $0.05)$. It means that the research data of Integrin $\beta 3(\mathrm{pg} / \mathrm{ml})$ has the same variant (homogeneous). Then the data proceed by Anova test to find out whether there is an effect of the purple sedge tubers essential oil on the $\beta 3$ integrin level of experimental animals, which is the value of $F=70,852$ with $p=0,000$.

Anova statistical test showed that there was an effect of the puzzle essential oil on integrin $\beta 3$ ( $p$ 0.00 ) in each group. Furthermore, differences were made between groups with the post hoc test as in the following table.

Table 1. Anova test effects of purple nutsedge tubers essential oil on $\beta 3$ integrin

\begin{tabular}{lll}
\hline Group & $\boldsymbol{\beta}$ Integrin levels & $\mathbf{p}$ \\
\hline C & $277,46 \pm 2,93$ & \\
T1 & $243,42 \pm 3,90$ & 0,000 \\
T2 & $265,83 \pm 4,98$ & \\
T3 & $257,13 \pm 4,59$ & \\
\hline
\end{tabular}

Table 2 shows that there is a significant difference in the level of $\beta 3$ integrin between the control group and P1, P2 when compared to the control. In this study, it was suspected that a decrease in the uterine $\beta 3$ integrin level of mice was caused by the effect of the essential oil of the tubers on the luminal epithelial cells and endometrial glands so that the endometrial response was reduced.

It is known that the essential oil of the tuber with its chemical content is cytotoxic and apoptotic to cells such as epithelial cells and endometrial gland cells [15]. The results of this study are in 
Table 2. Post hoc test $\beta 3$ integrin levels after giving purple nutsedge tubers essential oil

\begin{tabular}{lllcc}
\hline Group & \multicolumn{3}{c}{ T grade } \\
\cline { 2 - 5 } & C & T1 & T2 & T3 \\
\hline C & - & 0,000 & 0,000 & 0,000 \\
T1 & 0,000 & - & 0,000 & 0,000 \\
T2 & 0,000 & 0,000 & - & 0,002 \\
T3 & 0,000 & 0,000 & 0,002 & - \\
\hline
\end{tabular}

line with the opinion of Garrido et al. (2002) [16] that the expression of integrins in the endometrium provides an overview for the assessment of endometrial receptivity. Av $\beta 3$ integrins are produced by endometrial glands and luminal epithelium, with the implantation window opening. In the event of interruption/damage, the luteal phase will suppress the integration of $\alpha v \beta 3$ integrin during the implantation window. If integrins are found in low conditions this will indicate an effect on endometrial stimulation. Such cases are suspected due to interference / damage to endometrial receptivity.

A number of adhesion molecules, especially integrins, are expressed by the endometrium during the menstrual cycle and pregnancy. Integrins are needed for successful interactions between embryos and endometrium [17]. Reduced uterine receptivity and $\beta 3$ integrin expression result in endometrial abnormalities. This can be caused by several pathological disorders such as in the case of hydrosalpinges, endometriosis and damage in the luteal phase $[18,19]$.

The av $\beta 3$ integrin is closely related to the morphological maturation of the endometrial glands. Perfect growth of the endometrial gland expresses high levels of $\alpha v \beta 3$ integrin [20]. Disturbances in endometrial morphology can affect integrin expression when the implantation window opens. In this study, it is known that due to the administration of essential oils of rooting tubers causes low secretion of $\beta 3$ integrin during the process of implantation, this is thought to be due to the disruption of the morphology of endometrial cells [21].

Changes in the expression and distribution of integrin receptors in tropoblast cells are thought to cause the development of tropoblast attachment and displacement [22]. It is suspected in this study that giving fraction of essential oil of tubers causes disruption to the attachment and displacement of tropoblasts from blastocyst cells. This is in line with the opinion of Raghunathet al. (2009) [11] that some plants, including tubers of puzzles, are as antifertility, especially as blastocytotoxic. Thus it becomes clearer that integrin molecules have various expression patterns during the implantation window in the uterus and on the surface of the blastocyst [2].

\section{CONCLUSION}

In conclusion, the application of essential oils of purple sedge tubers reduce the levels of $\beta 3$ integrin of uterine mice during the embryo implantation period.

\section{ETHICAL APPROVAL}

As per international standard or university standard ethical approval has been collected and preserved by the author(s).

\section{COMPETING INTERESTS}

Authors have declared that no competing interests exist.

\section{REFERENCES}

1. Giudice C Linda. Potential biochemical markers of uterine receptivity. Hum. Rep. 1999;14(2):3-16.

2. Inan S, Giray G, Vatansever HS, Ozbiligin K, Kuscu NK, Sayhan S. Immunolocalization of integrin and fibronectin in tubal pregnancy. Acta Histochimia. 2004;10(3):235-243.

3. Bulleti C, Flamingi C, de Ziegler D. Implantation markers and endometriosis. Reprod Biomed Online. 2005;11(4):464468.

4. Nakayama J, Aoki D, Suga T, Akama TO, Ishizone S, Yamaguchi $\mathrm{H}$, Imakawa $\mathrm{K}$, Nadano D, Fazleabas AT, Katsuyama T, Nozawa S, Fukuda MN, Implantationdependent expression of trophinin by maternal fallopian tube epithelia during tubal pregnancies: Possible role of human chorionic gonadotrophin on ectopic pregnancy. Original Research Article. The American Journal of Pathology. 2003; 163(6):2211-2219. 
5. Naz RK, Gupta SK, Gupta JC, Vyas HK, Talwar GP. Recent advances in contraceptive development : A Mini Review. Human Reproduction. 2005; 20(12):3271- 3283.

6. Martin BJ, Suckow MA, Wolter WR, Berger $\mathrm{T}$, Turner JW Jr. Use of mucosal immunization with porcine zona pellucida (PZP) in mice and rabbits. Animal Reproduction Science. 2006;93:372378.

7. Krauss G. Biochemistry of signal transduction and regulation. $3^{\text {rd }}$ Completely Revised Edition. Wiley-VCH. Germany; 2003.

8. Devlin, Thomas M. Textbook of bichemistry. With clinical correlations. John Wiley and Sons, Inc. USA; 2011.

9. Staun-Ram E, Eliezer S. Human trophoblast function during the implantation process. Reprod Bioland Endoc. 2005; 3(56):1-12.

10. Kabir-Salmani M, Shiokawa S, Akimoto $Y$, Sakai K, Iwashita. M. The role of alpha(5)beta(1)-integrin in the IGF-Iinduced migration of extravillous trophoblast cells during the process of implantation. MolHum Reprod 2004;10(2): 91-97.

11. Raghunath D Pokharkar, Rajeshwari K.Saraswat, Minal G Kanawade. Contraceptive evaluation of oil extract of Mimosa pudica ( $L$ ) in male wistar rats 2009;3:479-488.

12. Susianti. Cytotoxyc effect of purple nut sedge tuber (Cyperus rotundus $\mathrm{L}$ ). Methanol and chloroform extract on HeLa and SiHa cells. Prosiding dalam pertemuan ilmiah tahunan ahli anatomi Indonesia. Yogyakarta, Indonesia: PAAl; 2009.

13. Kilani S, Sghaler BM, Limem I, Bouhlel I, Boubaker J Bhouri, et al. In Vitro evaluation of antibacterial, antioxidant, cytotoxic and apoptotic activities of the tubers infusion and extract of Cyperus rotundus. Bioresour Technol. 2008;99: 9004-8.
14. Sa'roni dan Wahjoedi B. Pengaruh infuse rimpang Cyperus rotundus $\mathrm{L}$ (teki) terhadap siklus estrus dan bobot uterus pada tikus putih. Jurnal bahan Alam Indonesia. 2002;1(2):45-48.

15. Kilani S, Abdelwahed A, Ammar RB, Heyder N, Ghedira K, Chraief I, Hammami M, Chekir-Ghedira. Chemical compotition, antibacterial and antimutagenic activities of essential oil from (Tunisian) Cyperus rotundus. J of Essential Oil Research. 2005;17(6):695-700.

16. Garrido N, Navarro J, Garcia-Velasco J, Remoh J, Pellice A, Simon C. The endometrium versus embryonic quality in ndometriosis-related infertility. Hum Reprod Update. 2002;81:95-103.

17. Achache $\mathrm{H}$, Revel $\mathrm{A}$. Endometrial receptivity markers, the journey to successful embryo implantation. Human Reproduction Update. 2006;6(6):731-746.

18. Creus MJ, Ordi F, Fabregues R, Casamitjana B, Ferrer , Coll E.. av $\beta 3$ integrin expression and pinopod formation in norman and out-of-phase endometrial offertile and fertile womwn. Hum.Reprod. 2002;17:2279-2286.

19. Avaris RF, Pedrini JL, Flores R, Fabris G, Zettler CG. Expression of $\alpha 1$ and $\beta 3$ integrin subunits in the endometrium of patientswithtubal phimosis or hydrosalpix. Fertil. Steril. 2006;85:188-192.

20. Apparao KBC, Lovely LP, Gui Y, Lininger RA, Lessey BA. Elevated endometrial androgen receptor expression in women with polycystic ovary syndrome. Biol Reprod. 2002;66:297-304.

21. Illera MJ, Cullinan E, Gui Y, Yuan L, Beyler SA, Lessey BA.. Blockade of the a $5 ß 3$ integrin adversely affects implantation in the mouse.Biol Reprod. 2000;62:12851290.

22. Fayazi M, Beigi Brojeni M, Salehnia M, Khansarinejad B. Ovarian stimulation by Exogenous Gonadotropin Decreases the Implantation Rate and Expression of Mouse Blastocysts Integrins. Iran Biomed J. 2014;18:8-15.

(c) 2019 Busman et al.; This is an Open Access article distributed under the terms of the Creative Commons Attribution License (http://creativecommons.org/licenses/by/4.0), which permits unrestricted use, distribution, and reproduction in any medium, provided the original work is properly cited.

Peer-review history:

The peer review history for this paper can be accessed here: https://sdiarticle4.com/review-history/51966 